\title{
Trade and investment: Introduction to the special issue
}

\author{
Renee Bowen $^{1} \cdot$ Manfred Elsig $^{2}$
}

Published online: 21 March 2018

(C) Springer Science+Business Media, LLC, part of Springer Nature 2018

\begin{abstract}
This special issue focuses on a variety of political-economy questions on trade and investment and is guided by a shared understanding that trade and investment processes can no longer be studied in isolation from each other. Three articles provide new insights into the study of the design of preferential trade agreements and effects thereof, two of which focus on the politically salient issues of non-trade concerns. A third one investigates which export sectors win from improved market access opportunities, in order words, how gains from trade are distributed. Two articles study the World Trade Organization's dispute settlement system. One contribution is unpacking the role of the most important and influential firms and investors in affecting US behavior in WTO disputes, a second contribution studies how leadership changes in democracies and autocracies have different effects on dispute behavior. Finally, the special issue includes a new study on how the shadow economies in developing states are affected by the integration into the world economy (trade and investment) and by policy programs of the International Monetary Fund.
\end{abstract}

Keywords Trade - Investment · World Trade Organization · Trade Agreements · International Monetary Fund · Labor · Environment

JEL classification $\mathrm{F} 13 \cdot \mathrm{F} 53 \cdot \mathrm{F} 60 \cdot \mathrm{K} 40$

Manfred Elsig

Manfred.Elsig@wti.org

Renee Bowen

trbowen@ucsd.edu

1 School of Global Policy and Strategy, International Lane, University of California San Diego, San Diego, CA 92093, USA

2 World Trade Institute, University of Bern, Hallerstrasse 6, 3012 Bern, Switzerland 


\section{Introduction}

Economic integration is driven mainly by increasing flows of investments, goods and services across borders. Since the end of the Cold War we have seen dramatic changes in transnational economic exchanges. Merchandise trade has increased in the past 20 years by over $300 \%$ from 5'176 Billion US\$ in 1995 to $15^{\prime} 986$ Billion US\$ in 2016. In comparison, services trade has increased by $400 \%$ from 1'222 Billion US $\$$ to 4'879 Billion US\$ over the same time span. Finally, the growth of foreign direct investments (FDI) has surpassed goods and services trade in relative terms over the same period. Global FDI stock increased more than 500\% since the mid-1990s from 341 Billion US\$ to 1'746 Billion US\$. ${ }^{1}$ Today, market structures themselves have created strong incentives for further liberalization, as many economies increasingly depend on imports for domestic consumption, production and re-export. The more countries rely on global and regional value chains, the greater the demand for trade liberalization (Baccini et al. forthcoming).

These transformations have been shaped by an increasing number of institutions that regulate trade and investment flows. However, the fields of international trade and investment regulation have been following different paths. Trade regulation has been centered in the second half of the twentieth century around successive steps of multilateral liberalization, backed up, since the mid-1990s, by a strong dispute settlement system with the creation of the World Trade Organization (WTO). The beginning of the twenty-first century has seen the revival of bilateral and plurilateral trade arrangements. Preferential trade agreements (PTAs) have mushroomed and have become deeper over time (Dür et al. 2014). They have replaced the WTO as an engine of liberalization. Figure 1 maps the depth of agreements over time as measured by commitments that affect market integration. In contrast, the field of investment regulation has been dominated by a bilateral approach through investment agreements (BITs) for decades. Over the past 60 years, states have signed more than 3000 investment agreements. BITs have been designed to protect foreign investment from direct or indirect forms of expropriation and many include investor-state arbitration procedures, where individual firms can sue governments directly bypassing the usually known forms of state-to-state arbitration in international cooperation. More recently BITs have attracted criticism that they would curtail policy space for governments to pursue legitimate societal objectives leading to terminations and re-negotiations of existing agreements (Haftel and Thompson 2018).

Whereas conventional wisdom holds that trade and investment liberalization are two sides of the same coin, research communities on trade and investment for a long time developed largely in isolation from each other. Trade and investment law has had little overlap, not least because dispute settlement systems were designed in substantially different terms. Trade disputes were dominated by state-to-state arbitration and an appeal instance at the WTO which has been making binding judgments on WTO members. By contrast, investment arbitration occurred either in the domain of private commercial law or firms could rely on investor-state arbitration to sue governments directly. Research on the political-

\footnotetext{
${ }^{1}$ UNCTAD Statistics
} 


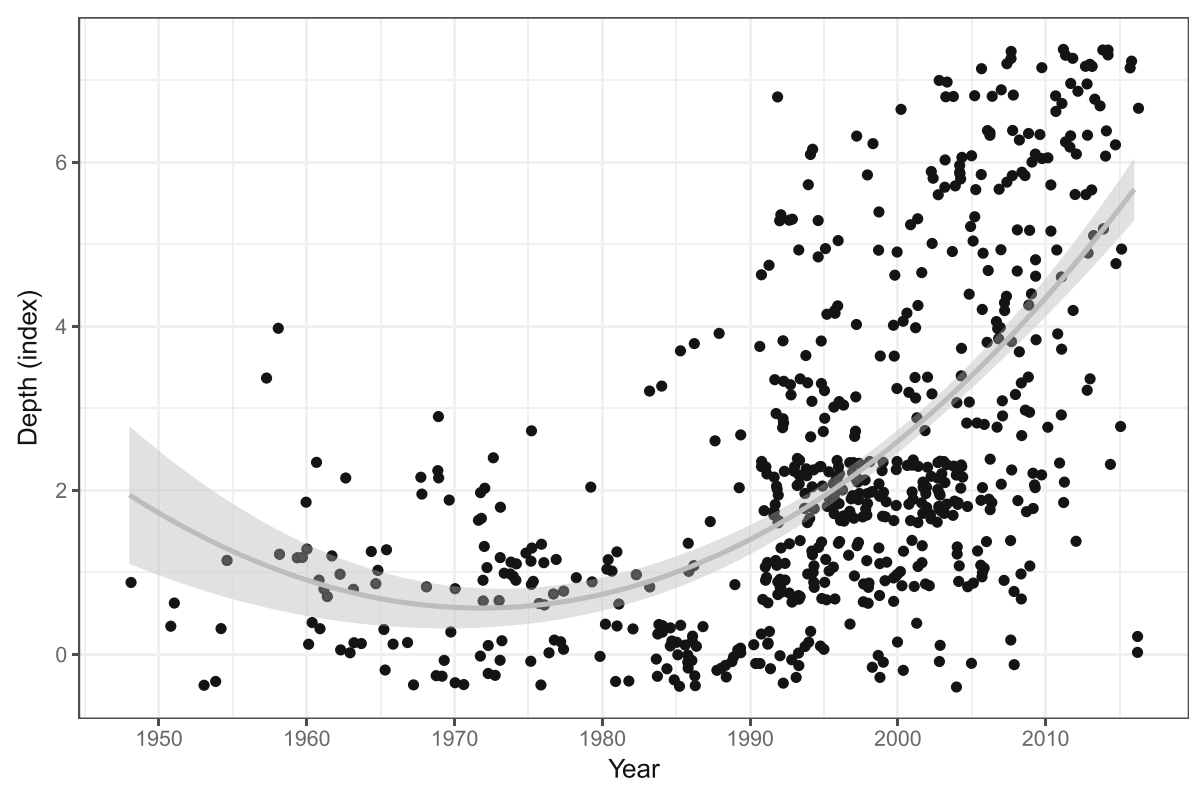

Fig. 1 PTAs and depth over time. Source: www.designoftradeagreements.org

economy of trade and investment was also following distinct pathways as scholars specialized either in trade or investment. Only recently, efforts were undertaken to engage more across these sub-fields, a development that has been supported by IPE conferences that brought together different scholarly debates. This increasing cross-fertilization and convergence has also been visible in international treatymaking as PTAs have not only become the most important institutional tool to regulate global trade, but today also overwhelmingly integrate investment chapters. The US for example has so far ratified 14 PTAs of which 13 have included an investment chapter. ${ }^{2}$ The EU has only recently started to include investment chapters as a result of constitutional changes within the EU. Since the successful adoption of the Lisbon Treaties, the EU institutions hold exclusive powers to negotiate FDI on behalf of the EU Member States. However, investment chapters have drawn significant criticism in various EU countries and have contributed to delaying the ratification of signed PTAs as witnessed recently in the adoption of the Canadian-EU trade agreement, called the Comprehensive Economic and Trade Agreements (CETA). The increasing politicization both in the US and in Europe about the impact of these agreements has further helped develop new strands of research tackling questions of "effects" on various economic and political parameters. The current IPE literature is paying more attention to both investment and trade agreements and new data efforts have allowed researchers to move away from treating international treaties as simple dummy variables. The literature on trade agreements for instance has focused on explaining design differences (Baccini et al. 2015; Allee and Elsig 2016, 2017) and has moved towards explaining economic and political effects.

\footnotetext{
$\overline{{ }^{2} \text { www.designoftradeagreements.org }}$
} 


\section{Contributions to the special issue}

This special issue follows above sketched new approach unpacking economic agreements and exploring design differences and treaty effects. Three of the articles focus on PTAs. Two articles provide new insights into the World Trade Organization's dispute settlement institutions and the final contribution looks at how the integration into the global economy affects shadow economies in developing countries, addressing the role of IMF programs in particular. Below, we highlight the unique contributions of each article in more detail.

The first article "Protecting labor rights in preferential trade agreements" presents fine-grained data on labor provisions in PTAs and tests a number of hypotheses accounting for design differences. The contribution by Raess et al. (2018) is one of the first large-N studies providing evidence that in particular the strength of trade unions is associated with stronger labor provisions. They also find that the effect of the strength of trade unions is conditional on both the presence of left governments and regime type. Finally, when focusing on the relative strength of high-skilled workers vis-à-vis low-skilled workers, they show that with increasing dominance of high-skilled workers, the depth of labor provisions decreases. This contribution nicely shows how the demand for higher labor standards is driven by domestic politics and in particular by trade unions, although it is important to account for the strength of high-skilled vs low-skilled workforce zooming in on a country's skill profile. They find no direct effect of left government on labor provisions.

The second article by Lechner (2018) also puts the focus on non-trade provisions in PTAs, namely environmental and labor provisions and explores the nexus with foreign direct investment. "Good for some, bad for others: US investors and non-trade issues in preferential trade agreements" is one of the first accounts on how these non-trade issues as standards affect business activities focusing on the behavior of US investors. Lechner hypothesizes that effects are heterogeneous across sectors in as much as non-trade standards should matter as a function of the type of industry (polluting and low-skilled labor endowed industries vs. environmentally-friendly and high-skilled labor abundant industries). She finds robust support for her argument using disaggregated US data providing unique evidence for the argument that non-trade provisions matter and in the suggested direction.

The third article "International trade at the margin: Estimating the economic implications of preferential trade agreements" takes on an important controversy about trade agreements effects on trade flows. Do they benefit new firms and new entrants or are PTAs just bolstering existing trade relations by increasing the volume for firms already active in the export markets? Spilker et al. (2018) evaluate these distributional consequences by focusing on what has been identified in the literature as the intensive (more volume in existing trade) vs extensive margins of trade (new traded products) effects. They rely on novel data from the Dominican Republic-Central America-United States Free Trade Agreement (CAFTA-DR) and exporting firms based in Costa Rica. The results of their study provide a nuanced picture. Trade effects are in particular conditioned by the type of product (whether it is a homogenous or a differentiated product) and the size of the firm. In relation to CAFTA-DR, they find that firms exporting heterogeneous 
products, such as textiles, gain from trade agreements, in so far as they sell more varieties of their products abroad. However, trade volumes (intensive trade) decrease. The effects of firms that engage in exporting homogenous products are exactly the opposite. This article nicely shows the importance of disaggregating export data and the differential effects PTAs have on trade flows.

The fourth article "Domestic political determinants of the onset of WTO disputes" by Rosendorff and Smith (2018) addresses the question how domestic politics affects dispute settlement behavior. The main findings of the article are first that change in leadership leads to dispute onset, and second, that the impact is greater in autocracies compared to democracies. They develop and present a model that links changes in trade policy and dispute onset to leadership change. They particularly focus on the level and effects of shifting constituencies on government support. They find that when leaders change in autocracies, new sectors enter the winning coalition, which in turn leads to more protectionism and results in more disputes. When leaders change in democracies, however, the change in the winning coalition is less acute, trade barriers are only increasing slightly, resulting in a less notable effect on dispute initiation.

The fifth article by Ryu and Stone (2018) is the first quantitative analysis on how Fortune Global 500 firms affect WTO disputes. In "Plaintiffs by proxy: A firm-level approach to WTO dispute resolution" they match data from firms having a stake in disputes to their lobby activities. Their analysis shows that firm lobby matters. Global 500 firms' political contributions are associated with USTR activities as they make it more likely that the US launches an official WTO dispute. The study also reveals that once a dispute is ongoing, firms tend to increase their lobbying. At the same time, lobbying is overwhelmingly "patriotic", meaning little evidence is found that large firms lobby (or counter-lobby) against domestic protectionist measures. When the US is the defendant in a WTO case, the authors find that lobbying makes swift settlement less likely as firms involved in the case are critical about concessions. Finally, Ryu and Stone also reveal mixed incentives when firms are supporting the complainant side.

The final contribution by Blanton et al. (2018) focuses on the shadow economies in developing countries and asks how economic globalization affects their development. In the article "Out of the shadows or into the dark? Economic openness, IMF programs, and the growth of shadow economies" they explore two distinct mechanisms. The first one explicitly focuses on the International Monetary Fund, an intergovernmental organization whose programs have often championed integration into the world economy. The second channel investigates the effects of increasing liberalization in trade in goods and services as well as investment. They argue that eliminating barriers to trade will make activities such as smuggling less attractive and will reduce the size of countries' shadow sectors. Also, access to global value chains will improve regulatory and labor-related policies in the formal sectors. As to IMF structural adjustment programs, the authors conjecture an opposite effect as these programs limit regulatory capacities of governments and bring about economic hardship in the short run, all of which increases the activities of the informal sector. The contribution tackles both trade and investment approaches and is one of the first contributions that sheds light on their immediate effects on shadow economies. 


\section{References}

Allee, T., \& Elsig, M. (2016). Why do some international institutions contain strong dispute settlement provisions: New evidence from preferential trade agreements. The Review of International Organizations, 11(1), 89-120.

Allee, T., \& Elsig, M. (2017). Veto players and the contents of preferential trade agreements. Review of International Political Economy, 24(3), 538-567.

Baccini, L., Dür, A., \& Elsig, M. (2015). The politics of trade agreement design: Revisiting the depthflexibility nexus. International Studies Quarterly, 59(4), 765-775.

Baccini, L., Dür, A., \& Elsig, M. (forthcoming). Intra-industry trade, global value chains, and preferential tariff liberalization. International Studies Quarterly.

Blanton, R., Early, B., \& Peksen, D. (2018). Out of the shadows or into the dark? Economic openness, IMF programs, and the growth of shadow economies. Review of International Organizations, 13. https://doi. org/10.1007/s11558-018-9298-3

Dür, A., Baccini, L., \& Elsig, M. (2014). The design of international trade agreements: Introducing a new dataset. The Review of International Organizations, 9(3), 353-375.

Haftel, Y., \& Thompson, A. (2018). When do states renegotiate investment agreements? The impact of arbitration. The Review of International Organizations, 13(1), 25-48.

Lechner, L. (2018). Good for some, bad for others: US investors and non-trade issues in preferential trade agreements. Review of International Organizations, 13. https://doi.org/10.1007/s11558-018-9299-2

Raess, D. Dür, A., \& Sari, D. (2018). Protecting labor rights in preferential trade agreements: The role of trade unions, left governments, and skilled labor. Review of International Organizations, 13. https://doi. org/10.1007/s11558-018-9301-z

Rosendorff, P., \& Smith A. (2018). Domestic political determinants of the onset of WTO disputes. Review of International Organizations, 13. https://doi.org/10.1007/s11558-017-9296-x

Ryu, J., \& Stone, R. (2018). Plaintiffs by proxy: A firm-level approach to WTO dispute resolution. Review of International Organizations, 13. https://doi.org/10.1007/s11558-018-9304-9

Spilker, G., Bernauer, T. Kim, I.S., Milner, H., Osgood, I., \& Tingley, D. (2018). International trade at the margin: Estimating the economic implications of preferential trade agreements. Review of International Organizations, 13. https://doi.org/10.1007/s11558-018-9306-7 